\title{
Planejar é preciso
}

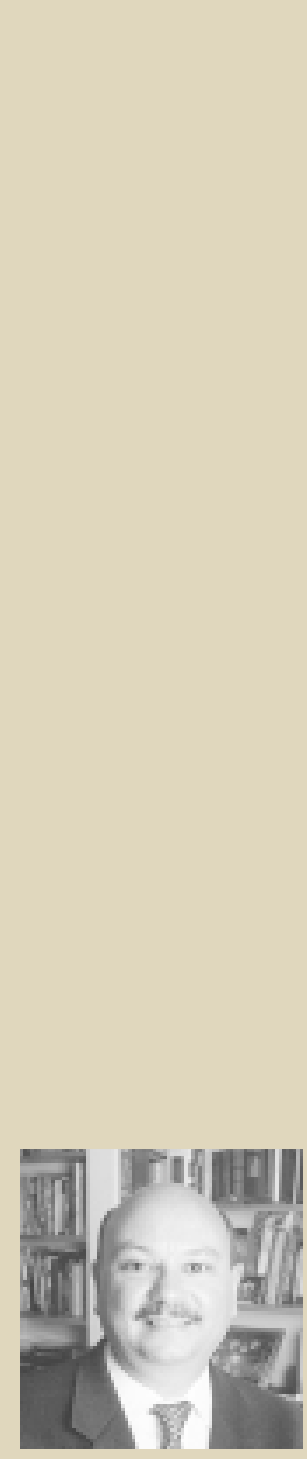

William Eid J $r$. FGV-EAESP

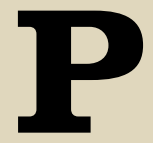

lanejamento é uma área com uma história interessante em administração e, em particular, em finanças, principalmente no Brasil. Mas ainda é considerada por muitos executivos como uma ferramenta de segunda classe. Podemos identificar dois motivos básicos para essa percepção: o primeiro é a inflação e o segundo é a ausência de tecnologia apropriada.

N ossa convivência com a inflação remonta aos tempos coloniais, e mais recentemente experimentamos taxas extremamente elevadas. Pior: taxas incertas. Projetar a inflação para o mês seguinte sempre foi exercício de pouca recompensa. Então, o que dizer das tentativas de projetar para um horizonte de um ano ou mais? E a inflação foi um determinante importante para a identificação dos outros números da empresa.

Paralelamente a esse fato, estivemos muito tempo à margem do desenvolvimento da informática que ocorria nos países centrais. Em tal contexto, a atividade de planejamento era prejudicada pela falta de flexibilidade. Como resultado, as empresas que se aventuravam a fazer planejamento no fim do ano concluíam, ao final do período seguinte, que haviam errado, e muito, em suas projeções.

Nossa herança não é muito boa. Mas há mais. Um planejamento eficiente demanda técnicas relativamente sofisticadas de projeção que são de conhecimento de poucos dirigentes de empresas. Elas estão agrupadas em uma área de estudo chamada Econometria, que real mente não é das mais simples e óbvias, exigindo forte base e bom entendimento dos conceitos e fundamentos. Essa dificuldade leva muitos executivos a desprezá-la como coisa de pouca utilidade prática. Ledo engano! 0 uso apropriado das técnicas econométricas pode ser de grande valia na realização do planejamento da empresa.

Finalmente, é importante assinalar dois aspectos importantes do planejamento e, em particular, das previsões. Primeiro, planejamento não é uma camisa-de-força. Ao contrário, ele tem de ser flexível. É só lembrarmos que ele está baseado em premissas sobre o futuro que muitas vezes não se realizam e concluiremos que a flexibilidade é fundamental. 0 segundo aspecto diz respeito ao objetivo das previsões. Ninguém pode esperar que um modelo matemático antecipe com exatidão a posição de uma variável econômica daqui a 12 meses. Então, qual é a utilidade das previsões? Com elas podemos construir cenários e, dentro de cada um deles, fazer previsões sobre o comportamento das nossas variáveis. E mais: podemos identificar quais são os direcionadores dos cenários para que possamos, com razoável antecipação, saber para qual deles estamos caminhando. Um bom planejamento deve contemplar al ternativas de ação para cada um dos cenários, o queé fundamental para o sucesso da empresa. 